\title{
Effect of High Pressure Processing on Enzyme Inactivation and Microbial Destruction of Sugarcane Juice
}

\author{
P. Sreedevi ${ }^{1 *}$, P. Srinivasa Rao $^{2}$ and P. Lalitha Kameswari ${ }^{3}$ \\ ${ }^{1}$ Regional Agricultural Research Station, ANGRAU, Anakapalle, AP, India \\ ${ }^{2}$ Agricultural and Food Engineering Department, Indian Institute of Technology, \\ Kharagpur-721302, West Bengal, India \\ ${ }^{3}$ Horticulture Research Station, SKLTSHU, Rajendranagar, Hyderabad, Telangana, India \\ *Corresponding author
}

\begin{tabular}{|c|c|}
\hline & A B S T R A C T \\
\hline $\begin{array}{l}\text { K e y w o r d s } \\
\text { High pressure } \\
\text { processing, } \\
\text { Polyphenol oxidase, } \\
\text { Yeast and mould, } \\
\text { Total bacterial } \\
\text { count, Coliforms. }\end{array}$ & $\begin{array}{l}\text { The shelf-life of fresh sugarcane juice is limited due to enzymatic browning and microbial } \\
\text { growth. Browning is caused by polyphenol oxidase (PPO) enzyme and the microbial } \\
\text { spoilage occurs mainly due to yeasts and moulds, aerobic bacteria and coliforms. High } \\
\text { pressure processing is one of the novel food preservation methods used as an alternative to } \\
\text { thermal treatment. The impact of high pressure processing (HPP) conditions on } \\
\text { physicochemical properties (colour, TSS, pH), PPO activity and microbial population of } \\
\text { fresh sugarcane juice was studied. The samples were pressurized at } 300 \text { and } 400 \mathrm{MPa} \text { for } \\
10 \text { to } 25 \text { minutes dwell time at ambient temperature }\left(25 \pm 2{ }^{\circ} \mathrm{C}\right) \text {. At } 300 \mathrm{MPa} \text {, the maximum }\end{array}$ \\
\hline Article Info & $\begin{array}{l}\text { of } 3.5,3.84 \text { and } 6.30 \log _{10} \text { cycles reduction was observed in total bacterial count, yeast } \& \\
\text { mould and coliforms respectively; whereas the numerals for those at } 400 \mathrm{MPa} \text { were } 4.44 \text {, }\end{array}$ \\
\hline $\begin{array}{l}\text { Accepted: } \\
\text { 21 August } 2017 \\
\text { Available Online: } \\
\text { 10 September } 2017\end{array}$ & $\begin{array}{l}5.31 \& 6.30 \log _{10} \text { cycles, respectively. The inactivation of PPO in sugarcane juice increased } \\
\text { with increase in either pressure or dwell time. Maximum of } 57 \% \text { inactivation of PPO was } \\
\text { obtained under } 400 \mathrm{MPa} \text { pressure at } 25 \mathrm{~min} \text {. No significant changes }(p>0.05) \text { were } \\
\text { observed in } \mathrm{pH} \text { and }{ }^{\circ} \mathrm{Brix} \text { and also the colour changes were not visually noticed }(\Delta E<2.5) \\
\text { for pressurized juice at different dwell times. }\end{array}$ \\
\hline
\end{tabular}

\section{Introduction}

Fresh sugarcane juice, a refreshing healthy drink, is a popular beverage relished by the consumers in many countries especially during the summer months. It is a cheap and high energy drink which is sweet, healthy and alternative to aerated drinks. Sugarcane juice is a nutritional product containing natural sugars, minerals and organic acids and has good medicinal properties. Being a health promoting food, it strengthens the stomach, kidneys, heart, eyes, brain and sex organs (Karthikeyan, et al., 2010).
As sugarcane juice is rich in sugars, it starts fermenting immediately after extraction and turns to brown due to polyphenol oxidase activity (Qudsieh et al., 2002). Besides endogenous enzyme activity, quality degradation due to microbial spoilage is also a factor of concern. Microbial fermentation of juice turns its taste to sour within hours of extraction (Yusof et al., 2000). These negative effects limit the preservation and marketing of raw sugarcane juice. Hence, development of a preservation method, which 
can control microbial growth in raw sugarcane and maintains its freshness, is a challenging problem.

Thermal processing is commonly used by the food industry for enzyme and microbial inactivation and is generally effective in this regard. However, thermal processing may cause undesirable changes in product's sensory as well as nutritional attributes, in specific to sugarcane juice it imparts jaggery flavour, which is undesirable for the consumer (Chauhan et al., 2002).Over the last 20 years, there has been a great deal of interest shown by both the food industry and academia in exploring alternative food processing technologies that use minimal heat and/or preservatives. One of the technologies that have been investigated in this context is high-pressure processing (HPP). HPP, otherwise known as high-hydrostatic pressure (HHP) and ultra-high-pressure processing (UHP), is a novel non-thermal technology that subjects juice products, or other foodstuffs, already sealed in their final packaging to high-pressure. HHP has been found to inactivate microorganisms and denature several enzymes without greatly affecting nutritional qualities. It has the potential to produce quality foods which are microbiologically safe with an extended shelflife. Application of High pressure processing on enzyme inactivation and microbial destruction for shelf life extension of fresh sugarcane juice was the principle objective of the current research.

\section{Materials and Methods}

\section{Preparation of sugarcane juice samples}

The Sugarcane variety 93A145 was selected for the study and the canes obtained from the Agricultural farm of Indian Institute of Technology were manually peeled, washed with fresh water and crushed immediately with laboratory model stainless steel sugarcane crusher (make: SGK Industries, Hyderabad). The juice $(50 \mathrm{ml})$ was then filtered for clarification using 3-layered muslin cloth and packed in low-density polyethylene (LDPE, $80 \pm 2 \mu \mathrm{m}$ ) films for pressure treatments.

\section{HP treatment}

Packed sugarcane juice samples were immediately pressurized at 300 and $400 \mathrm{MPa}$ for a dwell time of 10, 15, 20, $25 \mathrm{~min}$ in a batch mode HPP system (Model: S-I L-100250-09-W; Stansted Fluid Power Systems, U.K) having 2-L capacity cylindrical vessel with $100 \mathrm{~mm}$ inner diameter and $250 \mathrm{~mm}$ depth. The temperature of the immersion medium was sensed by a thermocouple and change in temperature of the immersion medium during pressurization was recorded using a programmable logic controller (PLC). All the samples treated at different pressure levels and dwell time were analysed for quality and compared with untreated juice samples.

\section{Microbial analysis}

The microbial load of the untreated and treated juice samples was determined using spread plate method. To prepare the dilutions, each of the duplicate treated pouches was opened under aseptic conditions and $1 \mathrm{ml}$ of juice was taken from each pouch, mixed with $9 \mathrm{ml}$ of sterile $0.1 \%(\mathrm{w} / \mathrm{v})$ peptone water. The detection limit of the analysis was $10 \mathrm{cfu} / \mathrm{ml}$. The total bacterial count (TBC) was determined after incubating at $37{ }^{\circ} \mathrm{C}$ for $18-24$ $\mathrm{h}$. The Yeast and mould count (YMC) was determined using potato dextrose agar (PDA) after incubation at $27^{\circ} \mathrm{C}$ for $36 \mathrm{~h}$. The coliform count was determined using violet red bile agar (VRBA) and the plates were incubated at $37{ }^{\circ} \mathrm{C}$ for $18-24 \mathrm{~h}$. After incubation, measurement was taken as colony 
forming units $(\mathrm{cfu} / \mathrm{ml})$. Analysis was done in triplicates and the mean value of $\log _{10} \mathrm{cfu} / \mathrm{ml}$ of the sample was reported.

\section{Measurement of enzyme activity}

\section{Enzyme extraction and assay}

Analytical grade chemicals, namely, Catechol, polyvinylpyrolidone (PVP) were used and PPO extraction was done for assay in $0.05 \mathrm{M}$ phosphate buffer of $\mathrm{pH}$ 7.0. Processed sugarcane juice of $1.5 \mathrm{ml}$ was mixed with $0.5 \mathrm{ml}$ of $0.05 \mathrm{M}$ phosphate buffer of $\mathrm{pH} 7.0$ and $0.1 \mathrm{~g}$ PVP in a $2 \mathrm{ml}$ micro tube and centrifuged at $10000 \mathrm{rpm}$ for 20 minutes at $4{ }^{\circ} \mathrm{C}$. The supernatant containing enzymes was taken out and PPO activity was assessed spectrophotometrically at $420 \mathrm{~nm}$, by recording the absorbance increase for 5 minutes. The sample cuvette contained 1.25 $\mathrm{ml}$ of $0.1 \mathrm{M}$ catechol with $1.55 \mathrm{ml}$ of $0.05 \mathrm{M}$ phosphate buffer ( $\mathrm{pH} \mathrm{7)}$ and $0.2 \mathrm{ml}$ sugarcane juice. The blank was prepared with $1.25 \mathrm{ml}$ of catechol and $1.75 \mathrm{ml}$ of phosphate buffer. Enzyme activity was calculated from the linear portion of plot of absorbance against time and expressed as $\Delta$ Abs.min ${ }^{-1} .(\mathrm{ml}$ sample $)^{-1}$. The relative activity $(\%)$ of enzyme was expressed as $\mathrm{A} / \mathrm{A}_{\mathrm{i}}$, where $\mathrm{A}_{\mathrm{i}}$ represents the initial activity of the enzyme in untreated sample.

\section{Physico-chemical properties}

\section{Colour measurement}

CIE colour parameter L*(lightness), a* (redgreen) and $b^{*}$ (yellow-blue) of the samples was estimated using portable colorimeter (Model: Spectro-guide 45/0 gloss; BYK Gardner, Germany). From the values of $\mathrm{L}^{*}$, $\mathrm{a}^{*}, \mathrm{~b}^{*}$, total colour difference $\Delta \mathrm{E}^{*}$ was calculated. $\Delta \mathrm{E}^{*}$ is a parameter that quantifies the overall colour difference of a given sample to a reference sample. It was calculated using the following equation:
$\Delta \mathrm{E}^{*}=\left(\left(\Delta \mathrm{L}^{*}\right)^{2}+\left(\Delta \mathrm{a}^{*}\right)^{2}+\left(\Delta \mathrm{b}^{*}\right)^{2)}\right)^{0.5}$

Where $\Delta \mathrm{L}^{*}=\left(\mathrm{L}_{1}{ }_{-} \mathrm{L}_{0} *\right), \Delta \mathrm{a}^{*}=\left(\mathrm{a}^{*}{ }_{1-} \mathrm{a}_{0} *\right)$, $\Delta \mathrm{b}^{*}=\left(\mathrm{b}_{1} *-\mathrm{b}_{0} *\right)$. Subscript ' 0 ' depicts the colour value for reference sample and subscript ' 1 ' depicts the colour value for the sample being analyzed.

\section{Total Soluble Solid (TSS) and pH measurement}

Total soluble solids (TSS) of the juice sample was determined using a digital hand refractometer (model: PAL-1; make; Atago, Japan).The $\mathrm{pH}$ of the sample was determined using a $\mathrm{pH}$ meter (model: 877, titrino plus, make Metrohm). $\mathrm{pH}$ indicator probe was inserted into the sample at $25{ }^{\circ} \mathrm{C}$ and stable reading was taken as $\mathrm{pH}$ value.

\section{Statistical analysis}

Significance test viz. Fisher's least significance difference (LSD) and Tukey's HSD test were carried out at $95 \%$ confidence interval for all the attributes in SPSS software version 2.0 (IBM SPSS Statistics, USA). Differences at $p<0.05$ were considered to be significant.

\section{Results and Discussion}

\section{PPO inactivation}

Polyphenol oxidase is one of the major oxidative enzyme involved in browning reactions, affecting the colour and flavour of food products (Zabetakis et al., 2000). Changing to brown colour affects the appearance and organoleptic properties of the products. Hence, inactivation of PPO enzyme is highly desirable. Inactivation per cent of polyphenol oxidase of sugarcane juice treated at $300 \mathrm{MPa}$ and $400 \mathrm{MPa}$ pressures at ambient temperature for dwell time of 10, 15, 20 and $25 \mathrm{~min}$ are summarized in table 1 . It was observed that the percentage of PPO 
inactivity increased significantly with increasing pressure and time from 10 to 25 min. Keeping the pressure same and increasing the dwell time, the rate of inactivation increased significantly.

The polyphenol oxidase inactivity in sugarcane juice after treatment at $300 \mathrm{MPa}$ at ambient temperature ranged from 37.0 to 57.0 $\%$ (Table 1). Also, with increase in pressure from 300 to $400 \mathrm{MPa}$, significant increase in PPO inactivation was observed. A maximum inactivation of $57 \%$ was observed in juice sample treated with $400 \mathrm{MPa}$. As reported by Chakroborty et al., (2012), PPO inactivation was50\% in strawberry puree under high pressure processing at $600 \mathrm{MPa} / 80$ ${ }^{\circ} \mathrm{C} / 10 \mathrm{~min}$. While in Apricot, strawberry and grape PPO inactivation could be achieved at pressures exceeding 100, 400 and $600 \mathrm{MPa}$ respectively (Hendrickx et al., 1998). Depending upon $\mathrm{pH}$, pressure of 100-700 $\mathrm{MPa}$ was needed for inactivation of apple PPO (Anese et al., 1994). Enzyme inactivation under high pressure domain is the pressure induced irreversible structural rearrangement from native to denatured state finally affecting its molar volume (Balny and Masson 1993; Gross and Jaenicke 1994).

\section{Effect on microorganisms}

The level of inactivation of pathogens in food deemed necessary to achieve an adequate margin of safety varies depending on the severity of the hazard posed by the organism, and whether subsequent handling and storage conditions are likely to increase the risk.

Table.1 PPO inactivation (\%) at 300 and $400 \mathrm{MPa}$ at different dwell times

\begin{tabular}{|c|c|c|c|c|}
\hline \multirow{2}{*}{$\begin{array}{c}\text { Dwell time } \\
(\min )\end{array}$} & \multicolumn{2}{|c|}{ Residual activity (\%) } & \multicolumn{2}{c|}{ PPO inactivation (\%) at } \\
\cline { 2 - 5 } & $300 \mathrm{MPa}$ & $400 \mathrm{MPa}$ & $300 \mathrm{MPa}(\%)$ & $400 \mathrm{MPa}(\%)$ \\
\hline 10 & $63 \pm 1.1$ & $59 \pm 2.2$ & $37 \pm 1.1^{\mathrm{bA}}$ & $41 \pm 2.2^{\mathrm{bB}}$ \\
\hline 15 & $58 \pm 2.0$ & $54 \pm 2.1$ & $42 \pm 2.0^{\mathrm{cA}}$ & $46 \pm 2.1^{\mathrm{cB}}$ \\
\hline 20 & $53 \pm 2.2$ & $48 \pm 2.5$ & $47 \pm 2.2^{\mathrm{dA}}$ & $52 \pm 2.5^{\mathrm{dB}}$ \\
\hline 25 & $49 \pm 2.0$ & $43 \pm 2.0$ & $51 \pm 2.0^{\mathrm{eA}}$ & $57 \pm 2.0^{\mathrm{eB}}$ \\
\hline Control & 100 & 100 & $0.0 \pm 0.0^{\mathrm{a}}$ & $0.0 \pm 0.0^{\mathrm{a}}$ \\
\hline
\end{tabular}

Values are presented as mean \pm standard error $(\mathrm{N}=6)$

Alphabets in small letters (a, b, and c) and capital letters(A and B) in the superscripts denote that the mean values are statistically different within the column and row respectively at $\mathrm{p}<0.05$.

Table.2 Total bacterial count (log cfu/ml) at 300 and $400 \mathrm{MPa}$ at different dwell times

\begin{tabular}{|c|c|c|c|c|}
\hline \multirow{2}{*}{$\begin{array}{c}\text { Dwell time } \\
(\mathrm{min})\end{array}$} & \multicolumn{2}{|c|}{$\begin{array}{c}\text { Total bacterial count } \\
\left(\log _{10} \mathrm{cfu} / \mathrm{ml}\right) \mathrm{at}\end{array}$} & \multicolumn{2}{c|}{$\begin{array}{c}\text { Reduction in Total bacterial count } \\
\text { (log cycles) }\end{array}$} \\
\cline { 2 - 5 } & $300 \mathrm{MPa}$ & $400 \mathrm{MPa}$ & $300 \mathrm{MPa}$ & $400 \mathrm{MPa}$ \\
\hline 10 & $4.78 \pm 0.31^{\mathrm{dA}}$ & $4.14 \pm 0.22^{\mathrm{dA}}$ & 1.77 & 2.41 \\
\hline 15 & $4.28 \pm 0.22^{\mathrm{cB}}$ & $3.48 \pm 0.16^{\mathrm{cA}}$ & 2.27 & 3.07 \\
\hline 20 & $3.80 \pm 0.21^{\mathrm{bB}}$ & $2.78 \pm 0.13^{\mathrm{bA}}$ & 2.75 & 3.77 \\
\hline 25 & $3.25 \pm 0.15^{\mathrm{aB}}$ & $2.11 \pm 0.11^{\mathrm{aA}}$ & 3.30 & 4.44 \\
\hline Control & $6.55 \pm 0.11^{\mathrm{e}}$ & $6.55 \pm 0.11^{\mathrm{e}}$ & & \\
\hline
\end{tabular}

Values are presented as mean \pm standard error $(\mathrm{N}=6)$

Alphabets in small letters (a, b, and c) and capital letters (A and B) in the superscripts denote that the mean values are statistically different within the column and row respectively at $\mathrm{p}<0.05$. 
Table.3 Yeast and mould count $\left(\log _{10} \mathrm{cfu} / \mathrm{ml}\right)$ and Coliforms count $\left(\log _{10} \mathrm{cfu} / \mathrm{ml}\right)$ at 300 and 400 $\mathrm{MPa}$ at different dwell times

\begin{tabular}{|c|c|c|c|c|c|c|}
\hline \multirow{2}{*}{$\begin{array}{c}\text { Dwell } \\
\text { time } \\
(\mathrm{min})\end{array}$} & $\begin{array}{c}\text { Yeast and mould count } \\
\left(\log _{10} \mathrm{cfu} / \mathrm{ml}\right)\end{array}$ & $\begin{array}{c}\text { Reduction in Yeast \& } \\
\text { mould (log cycles) }\end{array}$ & \multicolumn{2}{c|}{$\begin{array}{c}\text { Coliforms count } \\
\left(\log _{10} \mathrm{cfu} / \mathrm{ml}\right)\end{array}$} \\
\cline { 2 - 7 } & $300 \mathrm{MPa}$ & $400 \mathrm{MPa}$ & $300 \mathrm{MPa}$ & $400 \mathrm{MPa}$ & $300 \mathrm{MPa}$ & $400 \mathrm{MPa}$ \\
\hline 10 & $3.81 \pm 0.2^{\mathrm{dB}}$ & $3.15 \pm 0.15^{\mathrm{dA}}$ & 1.98 & 2.64 & $\mathrm{ND}$ & $\mathrm{ND}$ \\
\hline 15 & $3.20 \pm 0.25^{\mathrm{cB}}$ & $2.28 \pm 0.18^{\mathrm{cA}}$ & 2.59 & 3.51 & $\mathrm{ND}$ & $\mathrm{ND}$ \\
\hline 20 & $2.59 \pm 0.12^{\mathrm{bB}}$ & $1.4 \pm 0.11^{\mathrm{bA}}$ & 3.20 & 4.39 & $\mathrm{ND}$ & $\mathrm{ND}$ \\
\hline 25 & $1.95 \pm 0.05^{\mathrm{aB}}$ & $0.48 \pm 0^{\mathrm{aA}}$ & 3.84 & 5.31 & $\mathrm{ND}$ & $\mathrm{ND}$ \\
\hline Control & $5.79 \pm 0.21^{\mathrm{e}}$ & $5.79 \pm 0.21^{\mathrm{e}}$ & & & $6.3 \pm 0.21$ & $6.3 \pm 0.21$ \\
\hline
\end{tabular}

Values are presented as mean \pm standard error $(\mathrm{N}=6)$

Alphabets in small letters (a, b, and c) and capital letters (A and B) in the superscripts denote that the mean values are statistically different within the column and row respectively $\mathrm{p}<0.05$.

ND: not detected

Table.4 TSS and pH of sugarcane juice processed at 300 and 400MPa at different dwell times

\begin{tabular}{|c|c|c|c|}
\hline $\begin{array}{c}\text { Pressure } \\
(\mathrm{MPa})\end{array}$ & $\begin{array}{c}\text { Dwell time } \\
(\mathrm{min})\end{array}$ & $\mathrm{TSS}\left({ }^{\circ} \mathrm{B}\right)$ & $\mathrm{pH}$ \\
\hline 300 & 10 & $19.42 \pm 0.938$ & $5.10 \pm 0.063$ \\
\hline 300 & 15 & $19.55 \pm 0.938$ & $5.10 \pm 0.063$ \\
\hline 300 & 20 & $19.55 \pm 0.938$ & $5.15 \pm 0.063$ \\
\hline 300 & 25 & $19.50 \pm 0.938$ & $5.10 \pm 0.063$ \\
\hline 400 & 10 & $21.42 \pm 0.938$ & $5.18 \pm 0.063$ \\
\hline 400 & 15 & $21.32 \pm 0.938$ & $5.24 \pm 0.063$ \\
\hline 400 & 20 & $21.30 \pm 0.938$ & $5.22 \pm 0.063$ \\
\hline 400 & 25 & $21.25 \pm 0.938$ & $5.24 \pm 0.063$ \\
\hline Control & & $19.55 \pm 0.938$ & $5.11 \pm 0.063$ \\
\hline
\end{tabular}

Table.5 Change in colour values $(\Delta \mathrm{E})$ at 300 and $400 \mathrm{MPa}$ at different dwell times

\begin{tabular}{|l|l|l|}
\hline \multirow{2}{*}{$\begin{array}{l}\text { Dwell time } \\
(\mathrm{min})\end{array}$} & \multicolumn{2}{|l|}{ Change in colour values $(\Delta \mathrm{E})$ at } \\
\cline { 2 - 3 } & $300 \mathrm{MPa}$ & $400 \mathrm{MPa}$ \\
\hline 10 & $0.25 \pm 0.02^{\mathrm{aA}}$ & $0.85 \pm 0.07^{\mathrm{aB}}$ \\
\hline 15 & $0.67 \pm 0.05^{\mathrm{bA}}$ & $0.88 \pm 0.06^{\mathrm{aB}}$ \\
\hline 20 & $0.85 \pm 0.0 .06^{\mathrm{cA}}$ & $1.31 \pm 0.08^{\mathrm{bB}}$ \\
\hline 25 & $1.22 \pm 0.09^{\mathrm{dA}}$ & $1.67 \pm 0.07^{\mathrm{cB}}$ \\
\hline
\end{tabular}

Values are presented as mean \pm standard error $(\mathrm{N}=6)$

Alphabets in small letters (a, b, and c) and capital letters (A and B) in the superscripts denote that the mean values are statistically different within the column and row respectively $\mathrm{p}<0.05$. 
In addition to microbiological inactivation, the economic feasibility of HHP processing requires that treatment conditions be optimized to achieve the lowest pressure/shortest time combinations needed to eliminate pathogens of concern from the food to be treated. Treated and untreated sugarcane juice samples were analyzed for Total bacterial plate count (TPC), coliforms and yeast and mould count (Y\&M) and are presented in tables 2 and 3 .

Both intensity and duration of pressurization reduced total viable counts of microbes immediately after HP treatments. It was observed that the increase in dwell time from 10 to 25 min within same the pressure level, the total bacterial count and yeast and mould count decreased significantly. Also with an increase of pressure from 300 to $400 \mathrm{MPa}$, the total bacterial count and Yeast and mould count reduced significantly. At $300 \mathrm{MPa}$, the maximum of 3.30 and $3.84 \log _{10}$ reduction was observed in total bacterial count, yeast \& mould respectively; whereas the numerals for those at $400 \mathrm{MPa}$ were 4.44 and 5.31 respectively.

It was reported by Barros et al., (2005) that more than $4 \log$ cycle reduction was attained in Yeast \& mould count in pineapple puree treated at $400 \mathrm{MPa} / 30{ }^{\circ} \mathrm{C} / 10 \mathrm{~min}$ which was similar to the results obtained in the present study. The HPP treatment at $50 \mathrm{MPa}$ can inhibit protein synthesis in microorganisms and reduce the number of ribosomes and at $100 \mathrm{MPa}$, leads to partial denaturation and at $200 \mathrm{MPa}$ causes damage to cell membrane and internal cell structure.

Increasing the pressure to $300 \mathrm{MPa}$ or more induce irreversible denaturation of enzymes and proteins causing rupture to the cell membrane and the excretion of internal substances resulting in microbial death (Abe, 2007). No coliform count was observed in pressurized samples at both $300 \mathrm{MPa}$ and 400 $\mathrm{MPa}$ for the dwell times of 10 to $25 \mathrm{~min}$ (Table 3). Hence, coliforms were found to be pressure sensitive compared to total bacteria and yeast \& mould forms.

Microbial destruction effects of HP have been hypothesized to protein denaturation, cell membrane rupture and destabilization of cytoplasm contents due to increased membrane permeability which proves fatal for microbes (Meersman and Heremans, 2008). This may be the reason for microbial inactivation in HPP treated sugarcane juice.

\section{Effect on physical properties}

The effect of HPP on $\mathrm{pH}$ and TSS of sugarcane juice was summarized in table 4 . The $\mathrm{pH}$ of the sugarcane juice was found to be in the range of 5.10 to 5.24, which determines the minimal effect of pressure on $\mathrm{pH}$ of the product. As High pressure processing does not affect the covalent and hydrogen bonding, the $\mathrm{pH}$ remained constant before and after the treatment and has no effect. The TSS of sugarcane juice varies from 19.42 to 21.42 .

It was observed that with increase in pressure and dwell time, there is no significant effect on TSS of the sugarcane juice (Table 4). The change in colour viz., CIE-Lab values of the HPP treated sugarcane juice have been presented in table 5. The $\Delta E^{*}$ values increased significantly with increase in pressure and dwell time for HPP treated sugarcane juice. The $\Delta E^{*}$ values under combined pressure and time for the treated samples varied from 0.25 to 1.67.Color changes were not visually noticed $(\Delta E<2.5)$ for pressurized juice at different dwell time.

It was observed that with increase in pressure from 300MPa to $400 \mathrm{MPa}$ with constant dwell time, colour variation has increased 
significantly (Fig1). Also, with increase in dwell time, $\Delta E$ values increased significantly within same pressure.

However, the colour change was observed to be below 2.5 and cannot be visually noticed as per the categorization suggested by (Cserhalmi et al., 2006).

From the current study, high pressure processing at ambient temperature can be used as an effective technology to stabilize fresh sugarcane juice through reduction of microbial load and polyphenol oxidase activity thus preventing microbial spoilage with little changes in colour of sugarcane juice. However, further study has to be done to optimise the process parameters.

\section{References}

Abe, F., 2007. Exploration of the effects of high hydrostatic pressure on microbial growth, physiology and survival: perspectives from piezophysiology. Biosci. Biotechnol. Biochem., 71(10): 2347-2357.

Anese, M., Nicoli, M. C., Gianfranco, D. andLerici, C. R. 1994.Effect of high pressure treatments on peroxidase and polyphenoloxidase activities. J. Food Biochem., 18(4): 285-293.

Balny, C., and Masson, P. 1993. Effects of high pressure on proteins. Food Rev. Internatl, 9(4): 611-628.

Barros, A. M., Laboissier, L. H. E., Rosenthal, A., Camargo, L. M. A., Siqueira, R. S. and

Chakraborty, S., Mishra, H. N. and Knorr, D. 2012. Strawberry enzyme inactivation by HPP: Models \& contours. LAP LAMBERT Academic Publishing.

Chauhan, O.P., Singh, D., Tyagi, S.M. and Balyan, D.K. 2002. Studies on preservation of sugarcane juice. Int. J Food Properties, 5: 217-29.

Cserhalmi, Z., Sass-Kiss, Toth-Markus, M.and Lechner, N. 2006. Study of pulsed electric field treated citrus juices. Innovative Food Science and Emerging Technologies, 7(12): 49-54.

Deliza, R., 2005. Pineapple purée processed using high pressure. In: Enpromer.

Gross, M., and Jaenicke, R. 1994. Proteins under pressure.European Journal of BioChemistry, 212(2): 617-630.

Hendrickx, M., Ludikhuyze, L., Van den Broeck, I. and Weemaes, C. 1998. Effects of high pressure on enzymes related to food quality. Trends in Food Science \&Technology, 9(5): 197-203.

Karthikeyan, J., and Samipillai, S. S. 2010. Sugarcane in therapeutics. Journal of Herbal Medicine and Toxicology, 4(1), 914.

Meersman, F., and Heremans, K. 2008. High hydrostatic pressure effects in the biosphere from molecules to microbiology. In: Michiels c, Barlett D H and Aertsen A. (eds) High Pressure Microbiology. Washington, DC; ASM press, pp. 1-17.

Qudsieh, H.Y.M., Yusof, S., Osman, A.andRahman, R.A. 2002. Effect of maturity on chlorophyll, anin, colour and polyphenol oxidase (PPO) activity of sugarcane juice (Saccharum officinanum Var. yellow cane). J. Agri Food Chem. 50: 1615-1618.

Yusof, S., Shian, L.S.and Osman, A. 2000. Changes in quality of sugarcane juice upon delayed extraction and storage. Food Chem. 68: 395-401.

Zabetakis, I., Leclerc, D. and Kajda, P. 2000. The effect of high hydrostatic pressure on the strawberry anthocyanins. J Agric Food Chem, 48(7):2749-54.

\section{How to cite this article:}

Sreedevi, P., P. Srinivasa Rao and Lalitha Kameswari, P. 2017. Effect of High Pressure Processing on Enzyme Inactivation and Microbial Destruction of Sugarcane Juice. Int.J.Curr.Microbiol.App.Sci. 6(9): 2000-2006. doi: https://doi.org/10.20546/ijcmas.2017.609.245 